\title{
Ukrainian Linguistics in Canada: Second Half of the Twentieth Century and Beyond
}

\author{
Andrij Hornjatkevyč
}

University of Alberta

\begin{abstract}
In Canada, linguistic research into the Ukrainian language has appeared in both scholarly periodicals and in book form. For practical reasons, however, only published books will be examined here. These publications may be grouped into three major categories: language instruction, lexicography, and theoretical study. Furthermore, international borders were and continue to be porous: the works of Canadian scholars have been published abroad, while books by American scholars have been published in Canada. Consequently, major textbooks and learning grammars, lexicographic works, and books on theoretical issues dealing with Ukrainian linguistics by Canadian linguists and by foreign scholars published in Canada will be examined here.
\end{abstract}

Keywords: Ukrainian language, linguistics, Canada, grammar, lexicography, genitive singular masculine, imperative, aspect.

\subsection{LANGUAGE INSTRUCTION}

$\mathrm{N}$ umerous publications for use in preschool, elementary, and secondary instruction of the Ukrainian language have appeared, but since their linguistic component is limited, they shall not be discussed here. Only books, in particular textbooks intended for or used in tertiary (postsecondary) institutions, will be examined. The textbooks and grammars discussed are presented below in chronological order.

\subsection{GENERAL COMMENTS}

A Modern Ukrainian Grammar (1949) by Professors George S. N. Luckyj (1919-2001, then at the University of Saskatchewan) and Jaroslav B. Rudnyćkyj (Jaroslav B. Rudnyckyj, 1910-95, University of Manitoba) is an English adaptation of the latter's instruction manual first published in German in 1940; the latest version appeared in 1992 as the fifth, revised edition. It is clearly intended for adult learners who want to be able to read Ukrainian texts, but offers few opportunities for the development of conversational skills. 
Ukrainian Grammar (1966) by Julian W. Stechishin (1895-1971) is evidently intended for the student who may have some knowledge of Ukrainian but needs a firm grammatical foundation. The vocabulary is of a limited practical use in conversations.

Professor Andrij J. Hornjatkevyč (b. 1937, University of Alberta) first wrote his Contemporary Ukrainian (1975) for Harvard University students who already had a good command of another Slavic language (usually Russian) and would be able to apply what they already knew to the study of Ukrainian. He then made minor modifications to his textbook for students at the University of Alberta, who were predominantly of Ukrainian heritage. The book's vocabulary, to the limited degree possible, was adapted to the experience of a North American student in Ukraine.

Professor Danylo Husar Struk (1940-99, University of Toronto) likewise stipulated that his Ukrainian for Undergraduates (1978) "is primarily intended as a textbook for students with some previous knowledge of Ukrainian" (iii). In other words, his aim was to clean up students' native knowledge.

Conversational Ukrainian (1987) by Professor Yar Slavutych (19182011, University of Alberta) was originally published as a high school textbook, but the author, and probably others, have used it in post-secondary courses. This work is rich in cultural content, and has as its aim the improvement of conversational skills.

The goal of Professor Jaroslav B. Rudnyćkyj's Lehrbuch der ukrainischen Sprache (1992) is to improve his German-speaking learner's reading knowledge of Ukrainian. But it offers few opportunities for the development of oral skills.

Ukrainian for Speakers of English (1994) by Professor Roma Franko (b. 1936, University of Saskatchewan), although piloted at the University of Regina and the University of Saskatchewan, is intended for use in secondary schools, so its presentation and content are geared for that audience.

Modern Ukrainian (2001) by the Ukrainian-American professor Assya Humesky (b. 1925, University of Michigan), published in Canada by the Canadian Institute of Ukrainian Studies (CIUS) Press, is clearly intended for university students and contains appropriate vocabulary for oral use. The explanation of grammatical points is detailed and presented well.

Yar Slavutych's Standard Ukrainian Grammar (2004) is a scaled-down version of his Conversational Ukrainian, with significant loss of detail in the grammar presentation.

Ukrainian Through Its Living Culture (2010) by Professor Alla Nedashkivska (b. 1969, University of Alberta) is intended for advanced students who have already mastered the language's fundamentals. Grammar is discussed only in the appendices; the bulk of the textbook is devoted to the development of written and oral language skills in situations relevant to 
students. In contrast to virtually all of the previous works enumerated above, it deals with contemporary (and hip) Ukraine.

Unlike analogous publications that deal with other languages (e.g., French, German, Russian, Spanish), most of the above language textbooks and learning grammars of Ukrainian, their authors' occasional protestations notwithstanding, were written primarily for native speakers who needed theoretical grounding to support a competent (more or less) command of the language. All language textbooks include information about the culture, geography, and history of the country where the language is spoken, but the above textbooks and grammars of Ukrainian dwell on such topics to a far greater degree, frequently under the pretext of vocabulary development. However, they place the target language exercises in a somewhat artificial setting. With the exception of Nedashkivska's textbook, the conversations in the above textbooks are presented in a diaspora setting, where such conversations are unlikely. Meanwhile many real, everyday situations are glossed over or simply ignored.

The grammar is often presented under the presumption that the learner already knows Ukrainian to some degree. Nominal cases are often explained along the lines that the nominative case answers to the questions "who, what?"; the genitive, to "whose"?; the dative, to "for whom, for what?"; along with the Ukrainian "хто? що?; кого? чого?; кому? чому?" respectively; and so on. Such an approach might work for a student who has some knowledge of the target language, but it is of limited use to a learner starting from scratch.

Although all of the language textbooks and learning grammars examined here cover essentially the same grammatical information without significant differences, from a pedagogical viewpoint it is interesting to contrast the way these books treat certain grammatical structures. Specifically, three grammatical features are analyzed below: (i) the genitive singular of masculine nouns, (ii) the verbal aspect, and (iii) the imperative. These three are of particular interest because they display problems in selecting the proper suffixes. The criteria for selecting the genitive singular endings evolved in the early twentieth century, and this evolution is reflected in the textbooks. The verbal aspect category is not easy to define in simple terms, especially given the ramification of verbs of motion. Ordinarily the imperative is formed from the present stem, but accentuation patterns and stem-final consonant clusters play a decisive role in suffix selection. Therefore the learner must be taught to take many variables into account in order to produce the correct form. 


\subsection{Genitive Singular MASCULine}

Over the history of the Ukrainian language, the Common Slavic o-stem and $\mathrm{u}$-stem nouns merged into the masculine second declension with endings in -a and -u (а/-я and -y/-ю) in the genitive singular. Since no phonological or even historical criteria could be established as to which nouns will take which ending, grammarians have established semantic criteria for the choice. In the "Kharkiv" orthography Ukrains'kyi pravopys (Ukrainian Orthography, 1929), general guidelines were set up, but they are rather vague: nouns denoting persons and concrete or finite objects take the -a/-g endings, and abstract or less defined objects take the $-\mathrm{y} /$-ю endings. In the Ukrainian SSR the rules were modified throughout the 1930s, and reasonably firm rules were set down in the 1946 edition of the official orthography. Subsequently the rules were refined, but the basic rules formulated in 1946 remain even in the latest 2007 edition of the official Ukrainian orthography.

In A Modern Ukrainian Grammar, Luckyj and Rudnyćkyj give no rules about the two genitive singular masculine endings; they simply give that ending along with the nominative singular of each noun in the vocabulary of each lesson and in the lexicon at the end of the grammar. Thus no theoretical foundation to the question is established.

Stechishin attempts to solve the problem by giving the full declensional paradigm of every noun in the lesson vocabulary, but later gives the following rules.

Masculine nouns representing animate and inanimate concrete objects have the genitive singular in -a (-9) ... but there are masculine nouns that have the genitive case in -y if they belong to the hard declension, and -ю if they belong to the soft declension. The nouns in this latter class are: (1) collective and mass names; (2) names representing natural phenomena; (3) abstract nouns and those representing feelings; (4) nouns of action, derived from verbs; (5) foreign nouns and names of institutions; [and] (6) names of some countries, cities, and rivers. (160-61)

Stechishin sums up: "When a noun refers to some definite object or definite group, it has the genitive in -a (-я), and when it refers to an indefinite object, its genitive is in -y (-ю)" (161).

In his superb treatment of all facets of nominal declension, Terence R. Carlton states that the following nouns take -y (-ю) endings: (1) collectives, substances, materials; (2) large massive objects; (3) abstract nouns; (4) geographical names except those of settled points ending in -ов, -ев, - $€$ B, -ів, $-\ddot{B}$, and nouns with final stress. Consequently, all other masculine nouns take -a (-я) endings in the genitive singular (The Declension 42ff.). 
Hornjatkevyč's treatment of the -a (-я) vs. -y (-ю) genitive singular endings of masculine nouns follows the rules given in the 1960 edition of the official Soviet Ukrainian orthography (Ukrains'kyi pravopys), but departs from it in the treatment of names of settlements by trying to define what was left vague in the 1929 edition of the orthography (Contemporary Ukrainian 71).

In his treatment of the genitive singular of masculine nouns, Struk gives a very curt explanation of the $-y(-ю)$ usage, but no thorough explanation of the problem (26).

In his presentation in Conversational Ukrainian of the genitive singular of masculine nouns, Slavutych states that some take the (hard) ending -a, and some the ending -y "if the noun is of indefinite shape or abstract meaning" (7). In a subsequent lesson he introduces the soft ending -я (29) but says nothing about the alternate soft -ю ending nor does he comment on the distribution of $-\mathrm{a}(-9)$ and $-\mathrm{y}(-\circ)$ in the genitive singular of masculine nouns. In the book's Appendix (566-76), which gives complete declensional and conjugational paradigms, one has the impression that "animate" masculine nouns take -a (- 9$)$ endings-this is correct but incomplete-and that "inanimate" nouns take -y (-ю) endings, which is misleading at best. The glossary at the back of the book is of no help in this regard because only the nominative form of nouns is given. The vocabularies in each lesson are also of no help in this respect: while they offer the nominative plural of nounswhich is predictable-they fail to give the genitive singular. Thus Slavutych leaves the question of the genitive singular endings of masculine nouns unresolved.

In Standard Ukrainian, which is intended explicitly for use in universities, Slavutych only states that the endings -a (-я) and -y (-ю) are used in the genitive singular of masculine nouns (42), but gives no explanation of their distribution. Thus the student fares no better in this regard than with Slavutych's Conversational Ukrainian.

Franko (Ukrainian for Speakers of English 143) faces the -a (-я) and -y (ю) question squarely: the former endings are used with (1) concrete objects, (2) names of days and months, (3) some measurements, and (4) money; the latter endings are used with (1) collective units, (2) physical features, (3) foreign borrowings, and (4) abstract concepts.

Humesky states that the -a (-я) genitive singular masculine endings are used for (1) concrete objects, (2) certain types of measurements, (3) certain geographic names, and (4) surnames ending in -ін, -ів, -їв, -ськ, -ин, -ль, ик, -ок; while -y (-ю) endings are used by all others, i.e., (1) abstract notions, (2) institutions, (3) buildings, (4) collective nouns, (5) nouns denoting substance or material, and (6) most foreign borrowings, including geographic names (63). 
Rudnyćkyj gives the question of the genitive singular of masculine nouns short shrift: he states that the ending is -a (-я) and sometimes-y (-ю), but he does not elaborate (Lehrbuch 13, 34). He does, however, give the correct endings in the vocabulary at the end of the book.

Nedashkivska's Ukrainian Through Its Living Culture is intended for advanced students of the language, so presumably all points of grammar would have been dealt with in previous courses. Neither the vocabulary at the end of each lesson, nor the dictionary at the end of the book, gives the genitive singular masculine endings.

\subsection{IMPERFECTIVE AND PERFECTIVE ASPECT}

The phenomenon of aspect is alien to English speakers, so that category requires careful explanation.

Luckyj and Rudnyćkyj define the imperfective aspect as describing an action that (1) is still in progress and is incomplete, (2) will be taking place in the future, or (3) is complete, but the speaker is not aware of its completion (117). The perfective aspect describes an action or a state already completed or an action the completion of which is taken for granted. The authors, among others, do not provide for repeated completed actions, as expressed above all but not exclusively by verbs of motion. Furthermore, no provision is made for future perfective actions.

Stechishin's treatment of aspect is even more perfunctory: he states that the aspect is imperfective where "the action of the verb is not completed, finished or perfected" (74). Then he states that "in order to express a finished or perfected action, the Ukrainian language, like other Slavic languages, employs another verb, called the perfective verb" (75). Relying on a student's even defective knowledge, this author likewise does not provide detailed criteria for choosing the correct aspect.

Hornjatkevyč tries to simplify the issue by stating that the perfective aspect indicates a single and completed action (Contemporary Ukrainian 76). If both of these conditions are not met, the imperfective aspect must be used. Later he expands this concept to verbs of motion (205). The perfective aspect still refers to a single completed movement in a definite direction. Repeated or habitual (completed) movements are a subset-the nondetermined - of the imperfective aspect.

Struk states that the imperfective aspect describes (1) an action in progress over a period of time without reference to completion or termination, (2) actions performed repeatedly, and (3) actions spoken of in general terms (111). The perfective aspect describes actions brought to termination (111). 
Slavutych specifies that "the imperfective aspect denotes an unfinished action, repetition or continuity, while the perfective aspect denotes an action which is already completed, or will be definitely completed" (Conversational Ukrainian 41). Later he states that "the prefixes added to a verb in the imperfective aspect change its meaning" (317). (While this is often the case, the prefix may change only the aspect without changing the fundamental meaning: cf., писати-написати [imperfective-perfective] vs. писатипідписати [to write-to sign].) He expands the perfective aspect to designate the starting of an action (за- is an inchoative prefix). By "inserting the suffix -ува- (-юва) after the stem of the perfective aspect, we form the secondary imperfective aspect. The notion of it is 'to do repeatedly'" (318).

Franko defines the imperfective aspect as indicating an "ongoing, repeated, habitual or generalized action without indication as to the completion or termination of such an action" (199). The perfective aspect signals an action "already completed or terminated or will be in the future" (199).

Humesky specifies that the perfective aspect designates a concrete single action marked for "completion," while the imperfective aspect is unmarked for completion or indicates duration or habitual action (99). Thus it can be inferred that Humesky defines the perfective aspect as being "marked," and the imperfective as being "unmarked."

Rudnyćkyj deals with the problem of aspect curtly by stating that imperfective verbs describe an uncompleted action, and perfective verbs describe a completed action, or a state (Lehrbuch 76). But he expands that durative verbs express a lasting action or a state, while iterative verbs express a repetitive activity or a repetitive condition (78). As in his and Luckyj's A Modern Ukrainian Grammar, Rudnyćkyj does not elaborate any further.

Slavutych states that the imperfective aspect describes an action that is in progress, unfinished, repetitive or continuing, while the perfective aspect expresses the completion of an action or assurance that the action will definitely be completed (Standard Ukrainian Grammar 54).

As stated above, Nedashkivska does not deal with the question of aspect as part of the learning text, but examines it in Appendix IV 2.1. She defines perfective verbs as those "used to describe a single event in its entirety, stressing the result of a verbal action. Imperfective verbs are used to describe processes, ongoing events, and habitual actions or events" (281). She presents an excellent overview of the role of prefixes (and their absence) and certain suffixes in determining the aspect of a verb and when to use it (283). 


\subsection{IMPERATIVE}

The formation of the Ukrainian imperative is complicated because it involves the choice of stem-generally the non-past stem but occasionally the infinitive stem-the nature of the stem-final vowel or consonant, and the position of the stressed syllable in the first-person singular non-past. In this article only, "non-past" is used to indicate the present tense of imperfective verbs and the future tense of perfective verbs, since the endings are identical in each conjugation. Except for Hornjatkevyč (in Contemporary; 530 Ukrainian; Ukrainian Reference), none of the other authors use this term.

Luckyj and Rudnyćkyj specify that the endings -й, -ймо, and -йте are added to non-past stems ending in a vowel (112ff.). If that stem ends in a consonant, the endings are -и, -ім(о), and -іть (-іте). Short imperatives, i.e., the endings $-\varnothing,-$ Mo, and -те, are used on verbs ending in consonants that have the stress on the stem (and not on the ending). Where the stem of such verbs ends in a consonant other than the labials -p-, -ч-, -ж-, or -ш-, the ending is softened and written -ь, -ьмо, or -ьте. Exceptions to these rules are verbs that have two consonants before the non-past endings; these use the и, -ім(о), and -іть (-іте) suffixes in the imperative mood. These rules fail to work only with the verbs бити-б'єш and пити-п'єш, where the imperative is бий/мо/те and пий/мо/те, respectively. The authors do not mention ikannia (o > i) in the verbs стояти and боятися, which have imperatives стій/мо/те and бій/мо/теся, respectively.

Stechishin presents a similar solution (119). If the non-past stem ends in a vowel, the endings -й, -ймо, and -йте are added, but the verbs бити and вити have imperatives бий/мо/те and вий/мо/те, respectively. (One could add мий/мо/те.) If the non-past stem ends in a consonant and is the same as the infinitive stem (first conjugation only), the endings -и, -ім(о), and -іть (-іте) are used. But if the two aforementioned stems are different, the imperative endings are still -и, -ім(о), and -іть (-іте), but only if the "accent falls on the syllable just before the infinitive ending" (119)-hencе пиши, учи, шепчи. If the accent in any such verb is on a preceding syllable, the imperative will be as follows: пла́кати > плач/мо/те, кли́кати > клич/мо/те. Stechishin does not provide the rule for imperatives of -нути verbs or stem-stressed verbs ending in a dental consonant other than $\mathrm{p}$; ки́нути-кинь/мо/те or гла́дити-гладь/мо/те but ві́рити-вір/мо/те.

In Contemporary Ukrainian Hornjatkevyč tackles the imperative from the Jakobsonian ${ }^{1}$ basic stem (basically the longer of the infinitive or non-past stem) and proceeds to give the rules to produce the finite forms. However,

\footnotetext{
${ }^{1}$ See Roman O. Jakobson's seminal 1948 article "Russian Conjugation."
} 
he does not provide the imperative of бити > бий/мо/те, вити > вий/мо/те, and мити >мий/мо/те.

Struk gives an excellent presentation of the rules for the formation of the imperative (156-57). If the non-past stem ends in a vowel, the suffixes -

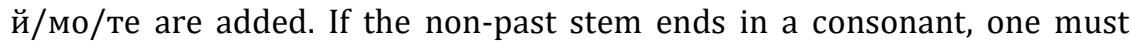
consider whether the first-person singular non-past ending is stressed. If the ending is stressed, the suffixes are $-и /$ ім/іть. If that ending is unstressed and the stem ends in a labial, sibilant, or $p$, the suffixes are $-\varnothing /$ мо/те; if the stem ends in a dental, the suffixes are -ь/мо/те. Struk also does not provide the imperatives of бити > бий/мо/те, вити > вий/мо/те, and мити > мий /мо/те.

Slavutych gives no rules for the formation of the imperative (Conversational Ukrainian 79). He simply gives a list of verbs in the imperative in groups of the type бери/ім/ть, вечеряй/мо/те, пий/мо/те, дякуй/мо/те, and бач/мо/те, with no further comments. Verbs of the глянь/мо/те type are not presented.

In Lehrbuch, Rudnyćkyj specified that non-past stems ending in a vowel take the imperative endings -й/ймо/йте. If the stem ends in a consonant, the endings are -и́/і́мо/і́ть (-і́те), but if the non-past stem ends in a consonant and is accented, it uses the shortened endings: i.e., - $\varnothing /$ мо/те, е.g., вір, вірмо, вірте; муч, мучмо, мучте; мов, мовмо, мовте. Furthermore, if this stem ends in a consonant other than a labial, p, ч, ж, or $ш$, the stem-final consonant is palatalized: e.g., радь, лізь, оr гинь. An exception to this rule obtains when the non-past stem ends in two or more consonants: the imperative suffixes are и/ім/іть, е.g., кисни, бубни. In contrast to Rudnyćkyj and Luckyj's much earlier Modern Ukrainian Grammar, the presentation of the imperative in Rudnyćkyj's Lehrbuch is much more refined.

Franko follows the same explanation as Struk, but she also accounts for бити > бий/мо/те, вити > вий/мо/те, and мити > мий/мо/те (297-301).

In her discussion of the imperative, Humesky takes the third-person plural non-past as the point of departure while specifying that the epenthetic л (after labials) must be deleted (133). The imperative suffixes are either $-\varnothing$ -

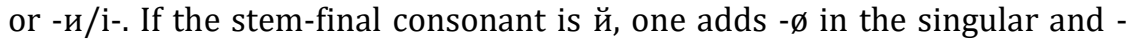
мо/те in the plural. However, if the first-person singular ending is stressed in the non-past, one adds the suffixes -и́/і́м/і́ть. If the non-past stem ends in

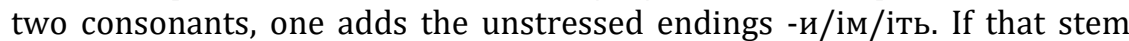
ends in a consonant, one adds $-\varnothing /$ мо/те; but if the consonant is $\mathrm{T}, \mathrm{д}, \mathrm{c}, 3, \mathrm{H}$, or л, it is palatalized and one adds -ь/ьмо/ьте. Humesky explains that ikannia occurs in certain verbs and the imperative of бути is будь/мо/те, but she makes no provision for verbs that form the imperative on the infinitive stem, such as бити, вити (в'ють), лити, or пити. 
Without giving any rules for the formation of the imperative, in Standard Ukrainian Grammar, Slavutych simply lists several verbs in the -и́/í- group, such as бери, -ай-, e.g., вечеряй, -й- пий, -уй- дякуй, and -ø - бач (80), in the presumed hope that the student's intuition will suggest what the imperative of any verb will be.

Nedashkivska gives a detailed presentation of the formation of the imperative in Appendix IV 2.3 (284). Like Humesky, her point of departure is the third-person plural non-past, minus the personal ending. If the stem ends in a vowel, the imperative endings are -й/ймо/йте. If the stem ends in a consonant, the position of the stress on the first-person singular non-past must be considered. If it is stressed, the imperative endings are -и́/і́мо/і́ть. If the stem is stressed but ends in two consonants, the endings are unstressed: и/імо/іть. If the stem is stressed and ends in one consonant, the endings are $-\varnothing /$ мо/те. The epenthetic л that occurs in the third-person plural non-past is deleted when the imperative is formed. Finally, if the verbal stem is stressed in the first-person singular and the stem ends in $\mathrm{T}, д$, с, 3, н, or л, the stem-final consonant is palatalized and the suffixes are ь/ьмо/ьте. Nedashkivska illustrates these points in a convenient table. Like Humesky, she does not provide the imperatives formed on the infinitive stem, such as бити, вити (в'ють), лити, or пити.

In both Humesky and Nedashkivska the apparent problem of the disappearing epenthetic л саn be obviated by simply choosing the secondperson singular non-past as a point of departure, as recommended by the other authors.

\section{LEXICOGRAPHY}

The outstanding Canadian work in this field remains Constantine $\mathrm{H}$. Andrusyshen and Jacob N. Krett's Ukrains'ko-anhliis'kyi slovnyk / UkrainianEnglish Dictionary (1955). It has been reprinted several times, most recently by the University of Toronto Press for the Canadian Institute of Ukrainian Studies (CIUS) in 1995-a clear indication of its timelessness. With over 100,000 entries, it was not exceeded by publications even in Ukraine until well after her independence in 1991.

In their introduction (in English), Professor Andrusyshen (1907-83, University of Saskatchewan) and Krett $^{2}$ give the customary general explanation of their dictionary's form (xi-xiii) and provide extensive

2 Jacob N. Krett (Ukrainian: Iakiv Kret, 1883-1965) immigrated to Canada from Galicia in 1907 and established a Ukrainian printing house in Winnipeg in 1908. Soon after, he compiled and published an English-Ukrainian pocket dictionary (1912) for Ukrainian speakers in Canada. 
grammatical paradigms (xiv-xxiii). They acknowledge the official Soviet Ukrainian Ukrains'kyi pravopys of 1946 and describe how their dictionary entries may differ (xxiv-xxv). Their primary entries, however, are spelled according to the official Ukrainian orthography of 1928.

The dictionary's entries of nouns give the genitive singular; the adjectives are given in their masculine singular form, with the feminine and neuter endings in parentheses. Verbs are given in the infinitive along with the first- and second-person non-past, and are marked for aspect. Likewise, adjectives that can form adverbs by suffixation are marked with an asterisk. Besides standard literary forms, some primarily southwest Ukrainian dialectal forms are included and are clearly marked as such. As the publisher states, "the publication of this comprehensive dictionary almost fifty years ago was an important event in Ukrainian-Canadian scholarship. The Ukrainian-English Dictionary has remained unsurpassed for decades, a most useful work in its field" (back cover).

A Canadian first is Ukrains'kyi zvorotnyi slovnyk (1969) by Dr. Vasyl' Nin'ovs'kyi (1914-2002), sourced from Hryhorii Holoskevych's Pravopysnyi slovnyk (Orthographic Dictionary) minus proper nouns. Nin'ovs'kyi produced this first Ukrainian reverse dictionary while he was a graduate student at the University of Alberta in the 1960s. All of the entries are in alphabetical order, starting at the end of the word. Thus this reverse dictionary can serve as a dictionary of rhymes or as a convenient source for morphological analysis. For example, all reflexive verbs are together because they end in -ся; all verb classes, -(ув)ати, -ити, -іти, -оти, and -нути, fall together, as do all hard or soft stem adjectives, and so on. It took another sixteen years before a reverse dictionary was published in Ukraine, compiled using a computer by S. Bevzenko and a team of other Soviet scholars on the basis of the much larger corpus in the eleven-volume academic Slovnyk ukrains'koi movy (Dictionary of the Ukrainian Language). Nin'ovs'kyi, however, did his work by hand.

Two Canadian scholars prepared Ukrainian etymological dictionaries. Rudnyćkyj first began publishing his Etymological Dictionary of the Ukrainian Language in annual installments from 1962 to 1977, with a hiatus between 1966 and 1974 (volume 1, parts 1-6, and volume 2, parts 2-5). The remainder appeared in 1982; it seems to have been a sprint to the finish just to get the job done-Rudnyćkyj admitted in the epilogue to volume 2 that it was a crude compilation reproduced from publications and manuscripts (1126). Besides presenting the origin of a given word, he cites numerous derivatives of some key words.

Metropolitan Ilarion (Ivan Ohiienko, 1882-1972) claimed that his Etymolohichno-semantychnyi slovnyk ukrains'koi movy (Etymological and Semantic Dictionary of the Ukrainian Language, 1979-94) was both an etymological and a semantic dictionary, but etymology plays a decidedly 
secondary role. Only borrowings are given some etymological treatment; the origin of native words is traced only to Common Slavic or, more often, compared to New Church Slavic. Where relevant, origins are traced to Latin, Greek, or German. None of the Common Slavic forms are marked as reconstructed $(*)$, and the hypothetical source language is presented as fact.

Metropolitan Ilarion's dictionary is a posthumous work: his disciple and editor, Jurij Mulyk-Lucyk, gathered Ilarion's existing publications and collated them into this dictionary. It is regrettable that the editor was not able to reproduce the Old Church Slavic nasal vowel letters $\mathrm{A}$ (e) and $\mathrm{n}(\mathrm{Q})$, which are simply presented by their subsequent East Slavic reflexes $я$ and y, respectively. Greek words are transliterated in Latin script, but the length or brevity even of mid vowels is ignored. Mulyk-Lucyk states in the preface that technical issues were the cause (10). The responsibility for these and other drawbacks of this work rest entirely on him and not on Metropolitan Ilarion. Thus the dictionary was a heroic effort, but its contents were not thoroughly compiled.

Maintaining the purity of the Ukrainian language, and especially avoiding the use of allegedly unnecessary foreign borrowings, has been a concern in the Ukrainian diaspora. Two such efforts by the émigré journalist Pavlo Shtepa (1897-1980) were published in Toronto. In his Znadibky do slovnyka chuzhosliv (Contributions to a Dictionary of Foreign Words, 1967), he made suggestions about how to replace borrowings with native Ukrainian words. Occasionally, however, one gets the impression that Shtepa created the words that he maintains should be used. His work was expanded and appeared as Slovnyk chuzhosliv (Dictionary of Foreign Words, 1977), but even there Shtepa proposes the replacement of legitimate Ukrainian words by supposedly better synonyms and substitutes certain foreign loanwords with others.

The year 1979 saw the publication in New York of Pravopysnyi slovnyk ukrains'koi movy (Spelling Dictionary of the Ukrainian Language) under the editorship of Rudnyćkyj and Kost' Cerkevyč (1911-87) of the Research Society for Ukrainian Terminology (Staten Island). It was actually a facsimile reprint of Oleksander Paneiko's Pravopysnyi slovnyk (Orthographic Dictionary, 1941), with minor emendations to the original lexicon and an addendum of toponyms (cities, rivers, mountains, islands, and states) with genitive and locative singular endings.

Following the example of similar publications of verbal paradigms of other languages, e.g., 201 German, Hebrew, Latin, Polish Verbs (to name but a few), followed by 501 French, Italian, Russian, Spanish Verbs (to name some more), Hornjatkevyč compiled and published 530 Ukrainian Verbs Fully Conjugated in All Tenses (2007) in electronic format. This work includes all irregular verbs and regular verbs with the highest frequency of use. The electronic format allows for easy searching through hyperlinks between 
Ukrainian or English indices and the verbs in question. Included is a detailed study of Ukrainian verbs in their strictly verbal forms (infinitive, non-past, future, etc.) and also deverbal forms such as the verbal substantive, participles, and gerunds.

\section{THEORETICAL WORKS}

Early in his teaching career at the University of Alberta, Professor Terence R. Carlton (b. 1934) wrote a number of small but extremely useful works for the student of modern Ukrainian. In A Student's Guide to the Pronunciation of Modern Literary Ukrainian (1969), he examined articulatory phonology, proceeding to a study of the phoneme and its allophones; analyzed the interrelations between vowels and consonants; and devoted much attention to various assimilatory processes, in some instances going beyond what is generally accepted in standard pronunciation. Carlton's The Declension of Nouns in Ukrainian (1971) was briefly discussed above, but only regarding the genitive singular of masculine nouns. In this work he dealt with all aspects of nominal declension, devoting particular attention to cases where alternate endings obtain. Drawing on principles laid down in his Student Guide, Carlton devoted close attention to accentuation patterns and ikannia in the genitive plural, and provided a lucid explanation to the problem of masculine nouns ending in -ap-. Carlton then turned his attention to Ukrainian numerals. In The Numeral in Ukrainian: Its Forms and Uses (1972), he presented the declensional forms and examined the numeral in a sentence both as a single digit and as a compound number with nouns and adjectives. It is unfortunate that these works were published in small press runs and are now available only in libraries. One may be partially consoled that this information, though not in such rich detail, can be found in the various teaching grammars that have appeared since.

Carlton's magnum opus is his Introduction to the Phonological History of the Slavic Languages (1991), a detailed examination of the evolution of the individual Slavic languages in Indo-European and common Slavic contexts. Having laid down the historical fundamentals, Carlton examined the individual Slavic languages by presenting, inter alia, extensive comparative tables of lexemes in the individual languages. He gives extensive treatment not only to the standard ("literary") languages but also devotes much attention to their dialects.

A Historical Phonology of the Ukrainian Language (1979), by the prominent professor of Slavic linguistics George Y. Shevelov (1908-2002, Columbia University), was published in Germany for the CIUS. In this magisterial, revolutionary work Shevelov rejects the widely held view that Ukrainian, along with Belarusian and Russian, evolved from a hypothetical 
Common East Slavic language and coalesced from a series of dialects. To be sure, the written language was under the profound influence of Old and New Church Slavic, but they had little impact on the development of the vernacular.

Hornjatkevyč's Ukrainian Reference Grammar in English (2010) is an ambitious work. The author attempts to cover all aspects of Ukrainian grammar-phonology and morphophonemics, morphology (inflected and uninflected parts of speech), and syntax, including such questions as negation and orthographic conventions (punctuation, capitalization, and syllabification). Like Hornjatkevyč's 530 Ukrainian Verbs, this grammar is published in electronic format, with hyperlinks between the index and the text, and within the text itself. Drawing on his pedagogical experience, Hornjatkevyč tries to simplify morphophonemic changes in nominal and verbal inflections by setting up simple rewrite rules that allow the user to proceed from a theoretical underlying form to produce all the forms actually found in written text.

Dialectology was difficult to pursue in Canada. Whatever dialects Ukrainian settlers preserved after immigrating to Canada were levelled through intermixing and eventual loss through assimilation. Research in the field in Ukraine was next to impossible in Soviet times, but Professor Mykola Pavliuk (a.k.a. Nicolae Pavliuc, b. 1927, University of Bucharest, 1958-74, and University of Toronto, 1976-95) and his Ukrainian-Romanian colleague Professor Ivan Robchuk (a.k.a. Ion Robciuc, b 1936, Ploeşti University) amassed a rich corpus of data about Ukrainian dialects spoken in Romania. Their Ukrains'ki hovory Rumunii: Diialektni teksty (Ukrainian Dialects in Romania: Dialect Texts, 2003) is a collection of transcriptions from four regions-Maramureş, Suceava, Dobrogea, and Banat. The first three are contiguous with Ukrainian territory and constitute a continuation of Transcarpathian and Hutsul, Bukovynian and Pokuttian, and Steppe dialects, respectively. The Ukrainian spoken in Banat reflects the dialects of Transcarpathian settlers in that area. Pavliuk and Robchuk provide a detailed discussion of the grammar of these dialects and how they were influenced chiefly by Romanian but also by Hungarian and German languages. The transcribed texts not only give a detailed picture of the spoken language but also of the speakers' daily lives.

\section{CONCLUSIONS}

One can expect that the market for beginners' instructional grammars will increase and new manuals will appear on the foundation laid especially by Humesky. These will have to be adapted for learners who will study Ukrainian not as a heritage language-as was the case with many earlier 
works-but as a foreign language. They will have to reflect evolutionary changes in the Ukrainian language in independent Ukraine.

Gradually the groundbreaking lexicographic work done by Andrusyshen and Krett is being supplanted by Ukrainian-English (and English-Ukrainian) dictionaries compiled in Ukraine on the basis of a larger and more modern corpus. Furthermore, the need for specialized dictionaries in various professions-e.g., business, engineering, law, medicine, the sciences-is growing, and experts in Ukraine are best qualified to satisfy this need.

Six volumes of the planned seven-volume Etymolohichnyi slovnyk ukrains'koi movy (Etymological Dictionary of the Ukrainian Language) have already appeared in Kyiv under the auspices of the National Academy of Sciences of Ukraine. They render obsolete the pioneering Ukrainian etymological dictionaries that the Ukrainian-Canadian scholars Rudnyćkyj and Metropolitan Ilarion compiled. Again, as the lexicon of contemporary Ukrainian grows, this is a growth area for further research to be filled by scholars in Ukraine. Unfortunately, few if any younger scholars in the diaspora are venturing into this field, which requires a detailed knowledge of numerous source languages.

It is hoped that the Institute of the Ukrainian Language of the National Academy of Sciences of Ukraine, using contemporary methodology, will update the academic grammar from the 1960s and 1970s to reflect today's linguistic reality.

Finally, and unfortunately, few young Canadian scholars are venturing into the field of historical and comparative Slavic linguistics. To be sure, fundamental work was done above all by Shevelov in his Prehistory of Slavic (1964). Carlton's Introduction to the Phonological History of the Slavic Languages (1991) is a scaled-down version of Shevelov's vast material. The definitive work on Ukrainian historical grammar is, and will probably remain for many years, Shevelov's Historical Phonology of the Ukrainian Language (1979) published in Heidelberg for the CIUS. In 2002 the Ukrainian translation of this epochal work was also published under the aegis of the CIUS, this time in Kharkiv.

\section{Works Cited}

Andrusyshen, C. H., and J. N. Krett. Ukrains'ko-anhliis'kyi slovnyk / Ukrainian-English Dictionary. Assisted by Helen Virginia Andrusyshen, University of Saskatchewan, 1955.

Bevzenko, S., editor. Inversiinyi slovnyk ukrains'koi movy. Naukova dumka, 1985.

Bilodid, I. K., et al., editors. Slovnyk ukrains'koi movy. Naukova dumka, 1970-80. 11 vols. 
Carlton, Terence R. The Declension of Nouns in Ukrainian. Department of Slavic Languages, University of Alberta, 1971.

---. Introduction to the Phonological History of the Slavic Languages. Slavica, 1991.

---. The Numeral in Ukrainian: Its Forms and Uses. Department of Slavic Languages, University of Alberta, 1972.

---. A Student's Guide to the Pronunciation of Modern Literary Ukrainian. Department of Slavic Languages, University of Alberta, 1969.

Franko, Roma. Ukrainian for Speakers of English. Detselig Enterprises, 1994.

Holoskevych, H. Pravopysnyi slovnyk. 9th ed., Knyhospilka, 1962.

Hornjatkevyč, Andrij. Contemporary Ukrainian. Department of Slavic Languages, University of Alberta, 1975.

---. Ukrainian Reference Grammar in English. 2nd revised ed., Ukrainian Multimedia / Interactive Learning and Digital Publishing, University of Alberta, 2010.

---. 530 Ukrainian Verbs Fully Conjugated in All Tenses. Ukrainian Multimedia / Interactive Learning and Digital Publishing, University of Alberta, 2007.

Humesky, Assya. Modern Ukrainian. 3rd ed., Canadian Institute of Ukrainian Studies $P, 2001$.

Ilarion, Metropolitan (Ivan Ohiienko). Etymolohichno-semantychnyi slovnyk ukrains'koi movy. Edited by Jurij Mulyk-Lucyk, Tovarystvo "Volyn'," 1979-94.

Jakobson, Roman 0. "Russian Conjugation.” Word, vol. 4, no. 3, 1948, pp. 155-167.

Luckyj, George S. N., and Jaroslav B. Rudnyćkyj. A Modern Ukrainian Grammar. Ukrainian Free Academy of Sciences, 1958. Originally published by $U$ of Minnesota P, 1949.

Mel'nychuk, O. S., et al., editors. Etymolohichnyi slovnyk ukrains'koi movy v semy tomakh. Vols. 1-6, Naukova dumka, 1982.

Nedashkivska, Alla. Ukrainian Through Its Living Culture. U of Alberta P, 2010.

Nin'ovs'kyi, Vasyl'. Ukrains'kyi zvorotnyi slovnyk. Ukrains'kyi tekhnichnohospodars'kyi instytut, 1969.

Paneiko, Oleksander. Pravopysnyi slovnyk. Ukrains'ke vydavnytstvo, 1941.

Pavliuk, Mykola, and Ivan Robchuk. Ukrains'ki hovory Rumunii: Diialektni teksty. Canadian Institute of Ukrainian Studies / Shevchenko Scientific Society, USA / Ivan Krypyakevych Institute of Ukrainian Studies of the National Academy of Sciences of Ukraine, 2003.

Rudnyćkyj, Jaroslav B. An Etymological Dictionary of the Ukrainian Language. Ukrainian Free Academy of Sciences, vols. 1-2, sec.1; U of Ottawa P, distributor, vol. 2, sec. 2, 1962-82.

---. Lehrbuch der ukrainischen Sprache. 5th ed., Harrassowitz, 1992.

---, and K. Cerkevyč, editors. Pravopysnyi slovnyk ukrains'koi movy. Research Society for Ukrainian Terminology, 1979.

Shevelov, George Y. A Historical Phonology of the Ukrainian Language. Carl Winter Universitätsverlag for the Canadian Institute of Ukrainian Studies, 1979. Ukrainian trans.: Iurii Shevel'ov. Istorychna fonolohiia ukrains'koi movy. Translated by Serhii Vakulenko and Andrii Danylenko, Akta, with the support of the Canadian Institute of Ukrainian Studies, 2002.

---. A Prehistory of Slavic. Carl Winter Universitätsverlag, 1964.

Slavutych, Yar. Conversational Ukrainian. 3rd enlarged ed., Gateway, 1987.

---. Standard Ukrainian Grammar. 3rd ed., Slavuta, 2004. 
Stechishin, J. W. Ukrainian Grammar. Trident Press, 1966.

Shtepa, Pavlo. Slovnyk chuzhosliv. Ivan Hladun and Son, 1977.

---. Znadibky do slovnyka chuzhosliv. Semen Stasyshyn, 1967.

Struk, Danylo Husar. Ukrainian for Undergraduates. Mosaic Press for the Canadian Institute of Ukrainian Studies, 1978.

Ukrains'kyj pravopys. Derzhavne vydavnytstvo Ukrainy, 1929.

---. Naukova dumka, 2007.

---. Ukrains'ke derzhavne vydavnytstvo, 1946.

---. 2nd revised and supplemented ed., Vydavnytstvo Akademii nauk Ukrains'koi RSR, 1960. 